\title{
BERA review 2006: education research and policy
}

\author{
Delma Byrne ${ }^{\mathrm{a}}$ and Jenny Ozga ${ }^{\mathrm{b} *}$ \\ ${ }^{a}$ Economic and Social Research Institute, Dublin, Ireland; ${ }^{b}$ Centre for Educational Sociology, University \\ of Edinburgh, UK
}

\begin{abstract}
The review examines the relationship between educational research and policy, from the post-war period to the present, throughout the United Kingdom. Its purpose is to (a) illuminate the changing relationship between education research and policy, and (b) to clarify the different ways in which that relationship is understood. Its overarching purpose is to enable the education research community to locate current debates about research and policy within historical and theoretical frames of reference, and to enable researchers to locate themselves and their work in this contested area.
\end{abstract}

\begin{abstract}
The review is structured in three main sections. The first explores the shifting meanings of research and policy, with attention to the ways in which particular definitions of research produce consequences for the ways in which policy is understood, and vice versa. From these discussions, which include differences between applied, basic and strategic research, and between 'policy science' and 'policy scholarship', the authors offer a typology of education research-policy relations. The second section explores the meanings of research and policy in historical context, and examines the growth of research in education from the post-war years to the 1960s and 1970s. Some of the key themes in the relationship are introduced, and the historical origins of some current controversies are traced and explored. The third section looks at the research-policy relationship in the current context, with attention to the growth of evidence-informed policy-making, and to major disputes and controversies about research quality and methodologies. Throughout the review the focus is largely on education research in England, but comparative points, drawn from the history and contemporary experience of the Centre for Educational Sociology (CES), are made about research-policy relations in Scotland, as are wider points about international developments.
\end{abstract}

Keywords: research and policy; evidence-based policy; research quality; policy science and policy scholarship

\section{Introduction: purpose of the review}

In recent years the relationship between research and policy has become a hot topic. Interest in that relationship, and arguments about what kind of relationship it is, and what kind of relationship it could or should be, have arisen in part from the increasing commitment of UK governments since 1997 to the principle of 'evidence-based' or 'evidence-informed' policy. As government apparently seeks guidance from research in shaping policy, so debates about the capacity of research in education to do this, and - perhaps more fundamentally - about the desirability of this close relationship between research and policy have grown in intensity (see, for example, Ball 2001; Hammersley 2002; Pring and Thomas 2004; Whitty 2006). The promotion by the UK government of an evidence-informed approach to both policy and practice raises a number of complex issues, and has a number of consequences, that affect the research and practitioner

\footnotetext{
*Corresponding author. Email: Jenny.Ozga@ed.ac.uk
} 
communities. For example, there is controversy over what counts as evidence, about the extent to which research in education should be steered by policy concerns, about the extent to which research is being used to justify policies that have already been decided upon, and about the possible narrowing of research agendas and privileging of particular methods that may follow from this close engagement with policy. Such disputes spill over into debates about research funding and tensions between accountability and autonomy in education research. The evidence-based approach provokes debate about the place of research in the professional formation and development of practitioners. It produces divisions within the academic research community in education.

The purpose of the review is to bring together and discuss the key features of scholarly literature that has addressed the research-policy relationship, either as the focus of research and scholarship, or as a 'by-product' of research on a specific policy case or issue. In constructing this review, we have also included some reference to official documentation where that relates to the policy-research relationship - for example, statements by ministers that set out their views of the place of research in policy. This review cannot fully engage with all of the issues raised by recent controversies and developments around the relationship between research and policy in education. It does not explicitly consider the relationship between research and professional practice, though this features as a sub-topic in some of the discussions below. Its focus is on the research-policy relationship as that relationship has been treated in the academic literature on education research and policy.

The review - like all the BERA (British Educational Research Association) academic reviews - tries to present an overview of the topic, based on our experience in this area, for a non-specialist audience. However, unlike other reviews, it is not able to identify a specific body of research-based knowledge (in the same way, for example, as could the BERA review on early years pedagogy) and assess it according to established criteria for systematic review of research. The policy-research relationship in education has not been the subject of an extensive body of research; instead it has emerged largely in the form of system descriptions (this is especially true of the older literature), as reflections and commentary from researchers who have studied education policy, and who draw conclusions about the nature of that relationship in the process of seeking to understand education policy - whether specific cases or as a topic in itself. Therefore the sources we have used extend beyond conventional research studies into a range of texts that debate the nature of the relationship. Summarising these texts presents some difficulties in that they represent many and varied positions held by researchers - this is a field where there is considerable controversy. We are also aware that the audience for this review consists of education researchers who are themselves caught up in the debates that it addresses. This is highly contested terrain: our approach has been to try to disentangle some of the main positions within these debates, and to set out their implications for understanding the policy-research relationship. The next section explains how we went about this task.

\section{Working methods}

In making a selection of texts, we were guided by our two main purposes or objectives, which were:

(a) to illuminate the changing relationship between education research and policy;

(b) to clarify the different ways in which that relationship is understood.

Why did we focus on these particular objectives? To a considerable extent, we were attempting to identify the key issues that underlie the rather heated debates about the relationship between education research and policy in the United Kingdom. Starting with a historical framing of the issue would, we thought, enable us to see the terrain more clearly by providing some distance 
from the immediate controversies. Objective (a), which commits us to looking at the relationship over time, and not just in the current context, also reflects our concern that the decline in the study of the history of education, combined with an ageing education research workforce (ESRC 2005; Lawn and Furlong 2007) produces a very short-term view of developments in the relationship. We feel that there is a need to document and discuss the history of research and policy as it has been seen in the literature, in order to better grasp what - if anything - is new about the current debates. This is particularly important in conditions where change is often experienced as threatening, and there is nostalgia for a lost 'golden age' (Power 1992; Ball 1997).

Objective (b) reflects our recognition that this area is marked by difference; among the main areas where disputes or differences arise are: (i) differences of view about the research-policy relationship expressed by researchers and policy-makers; (ii) debates among researchers about what the research-policy relationship should be; (iii) debates among researchers about how policy may be understood; and (iv) differences of view among researchers on whether research should be for policy or on policy. We set out to chart and explain the basis of these differences, and our aim has been to make the assumptions that inform them as clear and explicit as possible.

Our selection, therefore, does not review education policy as it affects different sectors or phases of education, nor does it include every publication that relates to a particular policy event or issue. Rather it focuses on those publications that have something to contribute to our key objectives.

Because our objectives put an emphasis on understanding change and difference, the work is organised around two main themes:

(a) a historical framework for understanding research and policy (1944/5-1980);

(b) a contemporary framework discussing current debates.

The review concludes with a discussion of the main points that emerge from these themes. Although many of the publications about research and policy have been produced by researchers writing about England, we have tried to reflect BERA's UK remit by discussing some inter-UK dimensions of these debates, by reference to our particular experience as members of a long-established research centre based in Scotland. We have drawn on historical and contemporary literature that considers the research-policy relationship through the lens of the experience of the Centre for Educational Sociology (CES), with reference to some wider literature, where it exists. The tendency for education researchers based in England to assume that 'the peculiarities of the English' (Seddon 1996) have global resonance and applicability is, in fact, a somewhat submerged or unacknowledged element of these discussions of education policy research, and we attempt to give it some attention.

\section{Review process}

The review process was guided by parameters of the key objectives, which informed the selection of materials under the two main themes identified above. The review began by using our experience and knowledge of the topic to make a preliminary identification of texts - both historical and contemporary. The process took shape by covering the major policy documents pertaining to education research and policy of the UK government, while also considering those of the devolved administrations. At the same time, academic works relating to commentaries on the education research and policy relationship were consulted. This had a 'snowball' effect as we then developed a larger selection on the basis of references that occurred within these key texts. We then used that larger collection as the basis for the development of a timeline of publications and 'events' (as can be seen from the references at the end of this text). 
We made extensive use of the many information resources available through the use of information technology, including CD-ROM databases and the Internet. The extensive e-resources at the University of Edinburgh provide access to well over 100 databases aiding bibliographic construction through the use of abstracts, indexes and bibliographic references to literature. Our use of electronic media extends to the resources of academic, public and commercial libraries in the United Kingdom and worldwide through various gateways (such as COPAC and the British Library and the Social Science Index, to name but a few). Searches were also conducted using bibliographic reference management software (EndNote Version 9), which we found to greatly facilitate desk research as it allowed interaction with online databases to construct bibliographies while storing and keeping records and notes of the relevant literature. In addition, the Centre's dedicated central repository brought together resources from across the research of the Centre.

Once we had constructed a fairly substantial endnote library, we drafted a first version of the review and presented this to an internal seminar of education researchers, and also sent it for comment to two education policy researchers.

Following discussion and feedback, it seemed necessary to clarify the focus of the review, and to underline the fact that we did not set out to make an analysis of specific education policies (for example choice of schools, or testing of pupil attainment). Nor did we attempt a comprehensive account of the development of policy to support or manage research (for example, through constructing a history of the research council). Both of these activities would contribute to knowledge of research and policy, but our focus was on the relationship between these two, drawing on the literature that specifically addressed this issue.

In working through the selection of texts that contributed to our account, we came to the conclusion that it would help to clarify our purposes, and help our 'reading' of these texts, to spend some time at the beginning of the review discussing the definitions of 'research' and 'policy' that are used in the literature and that inform, explicitly or implicitly, the discussions that we have attempted to summarise here. From these definitions, we were also able to develop a typology of the research-policy relationship, which draws on the literature on the nature of knowledge, combined with literature on the nature of policy-making. This, we hope, helps to clarify some of the main assumptions that are being brought into play in the texts that we discuss. Accordingly, the next section briefly considers some definitions of research and policy.

\section{Definitions of research and policy}

What is research?

We start with a recent, formal definition that reflects official policy concern for clarification in a context where watertight definitions are proving increasingly elusive. The OECD 'Frascati manual' (OECD 2002) distinguishes between three types of research, as follows:

- Basic research 'is experimental or theoretical work undertaken primarily to acquire new knowledge of the underlying foundation of phenomena and observable facts, without any particular application or use in view' (OECD 2002, 30). It contributes to a body of disciplinary knowledge: the aim is to produce knowledge, the audience is fellow researchers. This type of research is often described as 'blue skies' research.

- Applied research is 'original investigation in order to acquire new knowledge ... that is directed towards a specific practical aim or objective' (OECD 2002, 30). Thus, applied research differs from basic research in its explicit direction towards a practical end. The Rothschild report ${ }^{1}$ also distinguished applied from basic research on the basis of the existence of a clear contractual relationship between researchers and funders (Rothschild 1971) which he deemed not appropriate in basic research in the social sciences (Rothschild 1982). 
- Strategic research is a term used to define research that attempt to find a midpoint between these different definitions: thus it may be characterised by originality in the enquiry but responsive to particular needs, including policy needs.

Strategic research offers a compromise position between two more sharply differentiated extremes, and can be taken as reflecting developments in 'real life' enquiry, and/or as indicating the growth of 'steering' of research in all areas of science, and of increased contractual relationships between funders and researchers (Kenway, Bullen, and Robb 2004; Ozga, Seddon, and Popkewitz 2006). We offer these definitions to illustrate a continuum of possible positions in relation to the definition of research, and to illustrate the difficulty presented by definitions that seek to capture a range of activity, occurring in different contexts.

The variety of definitions of research that exist within education research is well known. This variety is a source of some concern to policy-makers and some researchers, but is also interpreted as a source of strength: a sign of vibrancy and capacity to respond to change. That variety contributes to strongly felt internal debates within the field about ways of defining quality, standards, evidence and impact, and constant fluidity and division within the field (Yates 2004, 2).

In the context of such diversity, Martyn Hammersley has argued that it is profoundly mistaken to suggest that basic and applied research form a continuum, or scale, with research designed for practical ends at one end of the scale and research with little or no connection to practice at the other end of the scale (Hammersley 2000a,b, 2002). Instead, Hammersley argues that basic and applied research are fundamentally different, that they occupy different positions in a status hierarchy and that the two-term distinction does not capture all the variation of social enquiry (Hammersley 2002). He proposes instead a distinction between 'scientific' and 'practical' enquiry, in which scientific research is:

designed to contribute to a body of disciplinary knowledge, so the immediate audience is fellow researchers, though the ultimate aim is to produce knowledge communicated through reviews of research findings in particular fields, that will be a resource for anyone with an interest in the relevant topic. (Hammersley 2002, 119)

This he differentiates from 'practical' enquiry, which is

geared directly to providing information that is needed to deal with some practical problem, so that the immediate audience is people with a practical interest in the issue; notably, but not exclusively, policymakers and occupational practitioners of relevant kinds. (Hammersley 2002, 119)

Hammersley further argues that the criteria of assessment of knowledge and for validating knowledge are critically different in these two forms of enquiry. Scientific knowledge, he argues, is collectively evaluated by the research community, and has general applicability; practical knowledge is assessed in relation to its relevance, and has local applicability. He maintains that both kinds of research cannot be done simultaneously without loss of quality, that each type has value (Hammersley 2000b, 124).

There have been a number of responses to Hammersley's arguments. A defence of the integration of scientific and practical research is offered by Anne Edwards in her presidential address to the BERA Conference in 2001. In this she argued that education research differed from discipline-based research as education research demands a different set of relationships with the field and with other researchers: relationships which

have at their core a set of value-laden concerns about individual, community and social well-being. These concerns mean that much of educational research is, and should be, a site of continual meaning making and they mark educational research as an activity in which engagement with its fields of study is crucial. (Edwards 2002, 1)

She goes on to say that educational research by necessity is close to both policy and practice, and that both versions of science (i.e. interpretive and data driven) are needed, in conversation with 
one another. She argues that research is strengthened by connecting correlational and interpretative analyses, as in the work of Sylva et al. (1999). Edwards further argues that exploitation of these resources, along with responsible engagement, can produce more fruitful research-policy relationships.

It can be readily seen that there is a short distance from formal definitions of the range of research activity in education, that seek to clarify categories, to major debates about the fundamental differentiation of types of research. Our concern here is to flag up the (perhaps rather obvious) fact that how research is defined and understood has considerable implications for its relationship with policy. Adherents of the existence of an essential difference between basic and applied research are likely to see basic research in education as following lines of enquiry and rules of validation that mark it off from policy: responsiveness to policy and practice is the province of practical, applied enquiry. In fact the literature on research and policy suggests very considerable variation in the way in which research is understood, and considerable differences about its capacity to inform policy and practice. In a recent intervention in these debates, Geoff Whitty advocates more careful use of the different terms 'education research' and 'educational research'. Education research is the term that could be used to characterise the whole field of research activity in education, he suggests, while educational research is used for work that is 'consciously geared towards improving policy and practice' (Whitty 2006, 173).

Let us move now to consider the equally contested area of definition of policy.

\section{What is policy?}

As with the definitions of research, our intention here is to flag up differences in the way 'policy' is understood, not to assess these approaches. Our purpose is to alert the reader to differences in definition and their implications.

As in the discussion of research definitions, it may be helpful to offer a series of contrasting positions, or polarisations of the kinds of approaches to conceptualising policy that feature, implicitly or explicitly, in the literature about education policy and research. By presenting these contrasting positions we hope to highlight key differences in approach.

We start with an approach developed by Roger Dale in which he distinguished a number of 'projects' in education policy (Dale 1986) - an approach drawn upon in Ozga (2000). The term 'project' is used to classify different purposes or meanings of policy. The essential distinction offered in this literature is between the 'social science project' and the 'policy analysis project'. The social science project is taken to be concerned primarily with understanding a problem or issue, using the resources of a discipline or disciplines of enquiry, whose value is judged by academic peers, and which adopts a comparative and historical perspective (Dale 1986, 100). This definition has clear parallels with the definition of 'basic' research outlined above. The policy analysis project is understood as oriented towards problem solving, as technical, rational and eclectic, and as seeking effective solutions. This 'project' perhaps aligns more easily with definitions of applied or strategic research, or with Hammersley's 'practical enquiry'.

Dale also identifies one further 'project' - the 'social administration project' - as having the following key features: a national focus, a prescriptive approach, a reliance on facts, and delivery through the structures of the post-war welfare state. This project, he suggests, characterises the work of education researchers in the post-war period, and up to the $1980 \mathrm{~s}$, when state-centred approaches to welfare provision were displaced by neo-liberal, market-orientated approaches. That connection of ways of thinking about policy to changing assumptions and practices in the wider political sphere underlines a further issue that requires attention in our consideration of the research-policy relationship - and that is the interaction between dominant modes of policy-making and research agendas and orientations. Researchers' approaches to 
theorising and exploring policy do not occur in a vacuum, but are responsive to political and social change. So researchers' definitions of policy are influenced by the current framing of policy. University-based research does not mirror the social and political context, but there are interconnections that link trends in theory and research to policy developments. Ball puts this more forcefully: "Research is thoroughly enmeshed "in" the social and "in" the political, and developments and innovations within the human sciences, like education, are intimately imbricated in the practical management of social and political problems' (Ball 2006, 15).

The policy analysis 'project' understands policy in formal terms, as the 'purposive action of government' or the 'authoritative allocation of resources', and there tends to be a focus on education as a distinct sphere of government, without much attention to other areas of social policy or to the wider economic, political and social context, or to ideological determinants of policy problems and solutions. This approach to policy is largely concerned with tracing stages and relations between different elements of a policy-making system. Policy is what is done in order to steer this system and maintain its coherence. The policy process is understood as sequential: (i) determining goals; (ii) choosing a course of action; (iii) implementing preferred courses of action; (iv) evaluating results (for efficiency and effectiveness); and (v) modifying policy. This process may be represented as a loop, or policy cycle, that moves from decision ... to implementation ... to evaluation ... and back to the decision. It is acknowledged that this orderly progression may not always occur in real life.

'Modified' policy analysis locates policy in a space between possibilities and constraints: choices are understood as being open to policy-makers but the scope for choice is acknowledged to be limited by previous choices and their consequences. Tension is part of the process: structure and choice are inextricably linked. More recent approaches attempt to take account of change: this is most evident in the growth of attention to policy networks. Policy network approaches include relational components of agency, power and interests. Members of networks do not have fixed or structurally 'given' interests. Instead there is a focus on contingent and processual outcomes of social relations between different actors (Ozga 2007).

Many different approaches could be contained within the umbrella heading of a social science 'project', which covers a very wide range of possibilities and resources, but with a shared commitment to using disciplinary resources to understand policy. It is likely that approaches to policy that draw on the wider social sciences will see policy-making as contested, and see power as a key dimension of policy-making. Power may be understood as coercive and concentrated in state agencies, or it may be seen as the effect of discursive practices and discourses that define objects or 'problems' that are to be subject to intervention, as well as specifying the solutions or responses to these problems. So, for example, political and policy discourse constructs an object (the welfare state, education) in such a way that it can be governed (Miller and Rose 1993, 79).

In education policy research these differences between 'projects' have been quite frequently characterised as differences between 'policy sociology' (Ozga 1987) and 'policy science' (Grace 1995). Among the main strands of this work we may identify the following key issues: Policy sociologists locate education and education policy in the context of ideological and political struggle. Policy is conceptualised as process; its exploration is located in a wide framework of enquiry in which 'education' is a part, but not the whole, and 'policy' as process is understood not as abstract and coherent but as 'incomplete and unstable' (Ball 2006, 17). Policy sociology is concerned with such questions as who defines policy? Who sets the agenda and in whose interests (Ozga 1987)? Such questions give rise to a number of working principles in seeking to explain education policy. These may be expressed as follows: (1) the need to locate change in education within a broad framework of enquiry, that takes account of exogenous, macro-social change; (2) the need to draw on resources from across the social sciences that enable understanding of that change; (3) the need for reflexivity in research that enables identification of the assumptions 
about the source, scope and pattern of education policy that are implicit in research on education (Dale 1986; Ozga 1987, 2000).

Stephen Ball has drawn on Gerald Grace's discussion of policy science and policy scholarship to illuminate the differences that we are seeking to highlight here. In Grace's words (drawing on Fay 1975), policy science is technical, abstracted, and problem solving in its orientation. Policy scholarship may be distinguished from policy science in the following ways:

Policy scholarship resists the tendency of policy science to abstract problems from their relational settings by insisting that the problem can only be understood in the complexity of those relations. In particular, it represents a view that a social-historical approach to research can illuminate the cultural and historical struggles in which schooling is located ... Whereas policy science excludes ideological and value conflicts as 'externalities beyond its remit'. (Grace 1995, 3, quoted in Ball 2006, 16)

These differences, presented - for the purposes of discussion - as reified binaries are used by Ball to construct a template that captures some key differences in education policy research, and that parallel quite closely the differences that we have attempted to identify in the discussion so far. The template (adapted from Ball 1997, 264) is reproduced below:

\section{A template [for characterising education policy research]}

(a) [design and scope]

Policy oriented

Practice oriented

Multi-focus

Multi-level

Temporal

Global/local

Linked focus

Single focus

single level

a-temporal

National/general

(b) [embeddedness]

Context rich

Detached

Conceptually 'thick'

Context barren

(c) [ethics of research]

Social justice

Critical

(d) [peopling policy]

Voiced

Conceptually 'thin'

Social Efficiency

Incorporated

Silent

Ball's key points about these binaries are as follows. In relation to the first set (design and scope), he suggests that much research in education does not deal with policy at all, but with classrooms, with teachers or with schools as though they were free-standing entities, without a policy context. A further point is that even where policies are given attention, researchers (whether policy scientists or policy sociologists) have a tendency to focus on one policy rather than on the interaction of - sometimes competing - policies. A further criticism relates to the absence of attention to time and space - the a-historicism of education policy research, and its insularity. The second set of criticisms is related to what Ball calls embeddedness, by which he means the absence of attention in education policy research to the wider developments in both social theory and social policy, so that education policy research fails, he suggests, either to draw on the full range of theoretical concepts available, or to locate education within a context of general economic and social change.

The third set of binaries, 'an ethics of research', captures the link between theory and research purposes. Here Ball argues for the capacity of theory to work 'on and against prevailing practices of ideological subjection'. He states: 
The point of theory and of intellectual endeavour in the social sciences should be, in Foucault's words, 'to sap power', to engage in struggle to reveal and undermine what is most invisible and insidious in prevailing practices (Troyna 1994). (Ball 1997, 269)

A little later in that paragraph he quotes a distinction that also illuminates the policy scholarship/ policy science difference very clearly, when he argues:

theory ... offers a potential location outside the prevailing discourses of policy and a way of struggling against 'incorporation'. To borrow Moore's formulation (Moore 1996, 159) it maintains the boundary between critical research 'of' policy and research 'on' policy. (Ball 1997, 269)

Ball's final binary draws attention to the tendency of some policy science approaches to 'abstract' policy and stress its formal elements, so that the research is either unpeopled, or populated only by 'first-order' policy-makers, who 'deliver' policy to 'second order recipients', who are then often characterised as failing to respond adequately to the demands of the policy in question. He points out that some policy sociology approaches, that define themselves as 'critical' education policy research, may also reduce people (whether teachers, parents or pupils) to caricatured victims or heroic resisters.

There is, then, a further set of polarised views about the definition of policy, to accompany differences in views of research. Our aim in drawing attention to these divergent views is to underline the ways in which they produce difference in conceptualising the relationship between research and policy.

These differences may be summarised as follows:

- Research and policy may be conceptualised as having an instrumental relationship: In this perspective, knowledge derived from research is understood as having the potential to be used directly in making decisions. There is an assumed direction of action as follows: from basic research to applied research to development to application. This could also be termed problem-solving: a problem arises - existing research is identified or new research commissioned - and a solution determined. Underlying this definition is an assumption of linear progression from applied to basic research, and of a linear process of policy-making that moves from recognition of a problem to action based on research. This conceptualisation of research-policy relationships assumes a continuum of basic and applied research (rather than a fundamental difference) and also suggests a policy analysis or policy scholarship approach to policy.

- Research and policy may be conceptualised as having an interactive or enlightenment relationship: This approach recognises that research is used alongside experience, political insights, and the opinions of different actors in a process that is not linear but interactive and possibly contested. The approach may connect to the emergence of 'strategic' research as a bridge between basic and applied, and it locates both research and policy in a wider social context, in which policy is less linear and more networked to different groups and interests in society. This approach relates to the idea that research knowledge is diffused throughout society and shapes policy-makers' thinking about specific policy decisions. It connects to Weiss's enlightenment model of gradual and dispersed research influence on policy (Weiss 1991). If contestation is admitted, then this categorisation could also include 'critical' policy sociology, in its role as 'sapping power'.

- Research and policy may be conceptualised as having a tactical relationship: This conceptualisation of the research-policy relationship restricts the role of research to one in which it supports a predetermined policy position: or that is used to enhance the credibility of policy-makers or practitioners, or that is used to promote the implementation of policy and practice decisions. This approach is unlikely to connect to basic research. 
I have to say, of course, that the great thing about research is that a part of it is rubbish and another part (I will not be specific about the proportions) leads nowhere and is really indifferent: it is, I'm afraid, exceptional to find a piece of research that really hits the nail on the head and tells you pretty clearly what is wrong or what is happening or what should be done ... People say they have done some research when they really mean they have stopped to think for three minutes. (Pile 1976)

\section{Part 1: Education research and policy 1944/5-1980}

\section{Research and policy post-war}

Before 1960 there was relatively little research on education in England, and policy-making is largely treated in the literature as the preserve of politicians, informed (and sometimes strongly steered) by administrators at central and local government levels (Gosden 1966; Kogan, Boyle, and Crosland 1971; Kogan and Mansfield 1975; Briault 1976; Lawn 1987). This was a way of doing things that was described as the post-war 'partnership' in education in England and Wales. The partnership between central and local government, and the teachers - who were viewed as partners 'less by legal status than by convention' (Weaver 1979, 32) - relied on a claimed 'consensus' about education (Musgrave 1970; Musgrove 1971; Baron and Howell 1974). The nature of the consensus may be open to debate (Lawn and Ozga 1986; Gewirtz and Ozga 1990): it depended on a degree of shared acceptance of the organisation of education on a selective basis for a school population differentiated by ability, which pursued distinctive trajectories towards different goals (Simon 1985, 1991). To the extent that this consensus operated, policy-making in education was hardly about policy at all, and is, indeed, described in policy and research texts of the period as administration (Birley 1970; Lawrence 1972). As a consequence, up to the period of post-war reconstruction in the 1940s and 50s, research in education in England was dominated by psychologically oriented empirical research on the measurement of intelligence and related ways of selecting children for special assistance or elite secondary education, or by pragmatic and class-based accounts of the system and its benefits (Nisbet 2005).

In contrast, education research was well established by the 1930s in Scotland, initially through a combination of key professors (with close connections to teacher education institutions), a supportive teachers' union and a significantly graduate profession, in comparison with England. By the 1930s, this had developed into a formal network, including the Directors of Education and the Scottish Council for Research in Education, funded by the union and the local authorities and by a substantial grant from the US Carnegie Foundation (Lawn 2004). The Council soon 'became the main source of authoritative research on Scottish education, especially in its pioneering surveys of school children' (Paterson 2003, 87). The data produced by national testing of all ten-year-olds in Scotland in 1932 and 1947 are valuable today in social research (for example, see Deary et al. 2004).

In England there are developments in the immediate post-war years, as the Labour government looks to research to enable its work of establishing the welfare state. The establishment of the National Foundation for Educational Research (NFER), initially on the Scottish model and also supported by a Carnegie grant, is one sign of a new interest in empirical data to aid policy-making. In particular there is a growth of the use of large-scale quantitative data throughout government at this time. Indeed, a DES report entitled Provision for Research, published in 1964, cites the important part played in the 'coming of age' of education research by the wartime need to classify service men and women and the post-war need to classify pupils (DES 1964). This emphasis on measurement and classification is represented in the growth of the 'political arithmetic' school of sociological research. The term itself is first evidenced in modern times, according to Heath, in Hogben's collection focusing on inequalities of access to grammar schools in England (Heath 2000; Hogben 1938, quoted in Heath 2000). In the broader context of the development of social science and its relation to social policy, from the mid-nineteenth century onwards, there is a relatively close 
link between social science and its development of a 'science' of society through statistical methods and policy-making, a link which centred on 'identifying and instituting suitable reforms for particular social problems' (Oakley 2000, 134).

\section{Political arithmetic}

The period of the 1940 s-60s may be seen as a high watermark in policy-research relations of a particular kind, in that connections in both directions were seen as quite stable and productive. By the 1970s, this 'political arithmetic' approach (Halsey 1997, 37) or, using Dale's (1986) term, the 'social administration' project, had begun to decline in influence. The political arithmetic tradition was and is a form of sociological enquiry that focuses on class-related inequalities, and it had and continues to have a strong focus on education and social class/social mobility (see, for example, Banks 1955, 1968; Floud, Halsey, and Martin 1956). Its main focus pre-war was on fee-paying grammar schools, and Heath records that the evidence produced in this work contributed to the provision of free secondary education for all in the 1944 Education Act for England and Wales (Heath 2000, 313). The distinguishing features of this approach have been: (i) its production and analysis of large-scale data that are authoritative and representative; and (ii) the emphasis on the capacity of such data to 'speak for themselves' in relation to social class and educational inequality.

The political arithmetic tradition continues and a strong focus on education remains (see for example, Halsey, Heath, and Ridge 1980; Heath and Jacobs 1999). Indeed there have been calls recently for a 'new' political arithmetic (Johnson 2004; Lauder, Brown, and Halsey 2004).

As education provision expanded in scale and scope from the end of the 1950s, policy-makers seem to have felt that they needed more information about what went on in education, in systems, local authorities and classrooms. Indeed, despite the growth and influence of the political arithmetic tradition, education research before the 1960s is characterised by Nisbet as:

a spare time amateur affair, unorganised and often ignored until its findings had percolated through into generally accepted values - an uncontrolled, slow, inefficient and (to administrators) - sometimes inconvenient process. (Nisbet 1985, 12)

The Crowther Report (Crowther 1959) drew attention to the lack of research in education, and suggested that the amount spent on education research was 'pitiable'. In 1964 the Schools Council for England and Wales was set up to promote work on examinations and curriculum research and development. Nisbet and Broadfoot (1980) argue that the pattern of increasing official support for education research (and later) development is similar to the more complex North American picture and was mirrored in other countries, which differed only in relation to the balance between government, university and autonomous institutions set up for this purpose. However, they argued that the true impact of education researchers in universities, government departments and research institutions at the time is difficult to disentangle from the host of other influences affecting educational change.

\section{The SSRC and the ERB}

From the 1960s onwards, increased official support for university-based research in the social sciences is demonstrated in the establishment of the UK Social Science Research Council (SSRC) in 1966. The SSRC established an Education Research Board (ERB) within it - which lasted until 1982. In this period, Nisbet argues, the ERB was seen by education researchers as a source of funds for basic or fundamental rather than applied research. Applied research was sponsored by the Department for Education and Science (DES), which had replaced the Ministry for Education, and whose support for such research was growing, but which also demonstrated in its internal growth and increasing sophistication the growth of 'official' expertise and a stronger role for 
professional experts (civil servants) in the management of an increasingly complex service (Pile 1976; Weaver 1979). In this period we also see the establishment by Claus Moser of a statistics branch in government, intended to create knowledge that supported policy-makers in recording social facts and in addressing and evaluating approaches to social problems.

The relative lack of investment in research to support policy-making was, however, a feature of criticism of the DES in the OECD's (1975) report on its operations and this was echoed in the House of Commons Select Committee report on policy-making in the Department of Education and Science, published later in the same year (Fletcher 1995). While intelligence-gathering and planning activities within the DES may have been strengthened, it is unclear that education research in the universities was regarded as significant by policy-makers, despite the activities of the ERB. As the quotation at the beginning of this section illustrates, the then DES Permanent Secretary, Sir William Pile, had no very high opinion of education research, and was particularly dismissive of its usefulness to policy (Pile, cited in Nisbet and Broadfoot 1980, 1).

\section{Sociology of education}

However, university-based research in education - and perhaps particularly in the sociology of education - did have connections to and influence on policy throughout the 1960s and early 1970 s, though this may be explained more in terms of a shared 'social administration project' than as a consequence of policy steering of research. In the 1960 s, there was a comparatively close relationship between education research and its 'parent' discipline sociology, and the context of policy-making (Deem, Parker, and Ozga 2004). Aspects of sociology's empirical methods, and also its conceptual and theoretical resources, were employed to investigate the structures and processes of schooling, and created research that came to exercise quite considerable influence upon policy-makers, particularly in relation to the issue of equality of opportunity in schooling. Here, there was a significant degree of concern amongst politicians that working-class pupils were being failed by the education system, and that, as a result, talent was being wasted. The work of Halsey, Floud, and Anderson (1961), Bernstein (1961) and Douglas (1964) is important and influential in England and beyond.

By the mid-1970s, a good deal of policy-related research in education was focused on race and gender, as well as class. Policy responses to concerns about discrimination related to race and gender were expressed in the Sex Discrimination Act (1975) and the Race Relations Act (1976). There was a great deal of debate among the research community about these policies and the role of the DES in promoting and implementing them. Some analyses understood policy as responsive to pressure from various interest and pressure groups (David 1977; Tomlinson 1984); others drew attention to the official capacity to maintain incremental and consensual approach to policy through 'low risk' reforms (Kirp 1984). As research on educational inequalities associated with race and gender produced evidence of sexism and racism in schools and local authorities (Dorn and Troyna 1982; Troyna 1982; Arnot 1983; Stanworth 1983; Weiner 1985), so the critical appraisal by researchers of policy interventions increased, and close relationships with policy became more difficult. At the same time, the influence of research on practice was possibly increasing, at least in part through closer relationships between researchers and some local authority policy-makers (ILEA 1982, 1983a,b, 1985; Royal County of Berkshire 1983). Research and practice were also connected through the activities of the teacher organisations (NUT 1982, 1984) and through the dissemination of research through Open University courses that were taken by large numbers of teachers in service (for example Open University 1981, 1986).

The turn in sociology of education away from a joint 'problem-solving' enterprise towards much more critical views of policy and its preoccupations reflected changes in the way that inequalities were understood by researchers, as well as a changed policy context and direction. 
Policy-makers were no longer understood as allies in a struggle against class-based inequalities, whose actions would address these problems, provided they were well-informed about them. As Young (2004) has commented, the tendency was to view policy as a means by which power and control operated, and policy-makers as complicit in the maintenance of unequal power relations. The sociology of education consequently became more focused upon unveiling the masked forms of power contained in policies. At the same time influential theorists underlined the inability of education to 'compensate for society' (Bernstein 1970), and its role in social reproduction was much stressed (Bowles and Gintis 1976; Bourdieu and Passeron 1977). Such ideas produced a strong reaction against the idea of policy as productive and of researchers having the capacity to contribute to solving policy problems.

Hammersley (2002) suggests that these shifts reflected change and expansion of education research in the 1960s and 1970s that resulted from the mergers of teacher colleges in England with universities, and the consequent demand for research activity to sustain a graduate profession. The foundations of undergraduate education in philosophy, psychology, sociology and history were areas that were themselves changing and fracturing, so that just as teachers and teacher educators were more engaged with research, the disciplinary formations with which they engaged were changing, becoming more fluid and uncertain. To add to this, policy-makers began to express dissatisfaction with teacher performance, and we see a growth of official criticism of the teaching profession throughout the 1970s in England, as the economic situation worsened and preoccupations with cost-effectiveness grew (Saran 1973; David 1977). This in part created, in part reflected the breakdown of 'consensus' about education. Hammersley talks about research in education becoming 'infused with radical ideas - anarchism and Marxism initially, feminism and anti-racism later' (Hammersley 2002, 2).

The often trenchant nature of the critical knowledge produced in the 1970s caused those in power to engage with it, but this engagement was of a wholly negative character, leading to a situation that saw 'the almost total disappearance of the sociology of education as a separate teaching subject from the syllabus of courses of initial teacher training' (Dale 1992).

Faced with growing hostility from policy-makers, research in education also changed, and turned away from overarching concerns with education's role in promoting or challenging inequalities towards more specific, and more classroom and practice-focused, enquiry in curriculum, in education administration and management, in school effectiveness research and in evaluation of specific policies throughout the 1980s. The funding of education research as a social science was affected by changes in the Social Science Research Council, which became the Economic and Social Research Council (ESRC) in 1981 and established a set of policy priorities that framed its work. Sir Keith Joseph was responsible for this change in the Council's name, as he did not accept that social sciences could be a 'science'.

\section{Education research in Scotland}

In Scotland throughout the 1960s there seems to have been a relatively strong convergence of interest between policy-makers at the then Scottish Education Department (SED) and university researchers, with research focused on topics that resulted from policy developments (the introduction of comprehensive education and the raising of the school leaving age) and focused on issues of curriculum, school management, pupil guidance and careers (Morris and Hope Johnston 1981). Research in Scotland seemed to follow policy, rather than influence it, and the impression given is of a small system, strongly influenced by Her Majesty's Inspectorate (HMI), in which research is not 'directly enmeshed' with policy decisions but helps to inform final decisions (Morris and Hope Johnston 1981, 211). These authors forecast a future of collaborative research development in Scotland in the 1980s, and identify trends towards collaborative research which include the 
work of the Centre for Educational Sociology (CES) and its Scottish Education Data Archive. The analysis of data, based on the Scottish School Leavers Survey, was collaborative, involving the Scottish Education Department, HMI, Directors of Education, teachers and researchers in analysis and interpretation of existing data and decisions about future topics of enquiry.

This rather benign characterisation of the relationship between research and policy expresses something of the nature of the 'policy community' in Scotland in this period, or rather of its representation of itself and its 'assumptive world' (McPherson and Raab 1988). A rather more critical view is offered by Humes (1986), who suggests that research was colonised by the SED (in part through the powerful influence, he suggests of J.G. Morris, one of the authors of the article quoted above). Humes argues that research in education in Scotland was pragmatic and defined in narrow, problem-solving and immediate terms. He also identifies a 'progressive loss of freedom to the research community' (Humes 1986, 161), pointing to increased SED influence over the Scottish Council for Research in Education (SCRE). Humes also discusses problems over 'the issue of control' of the Scottish School Leavers' Survey (SSLS), and provides an account of SED hostility to collaborative work, and to independent publication, that sits oddly with Morris and Hope Johnston's assessment of research and policy in Scotland. McPherson's (1976) account provides some support for Humes's critical position (see Humes 1986). His account of discussions with HMI about the publication of what was seen as an 'unhelpful' CES research report concludes with the statement that he was told that he could: " write what I liked" but that "I should not forget that Scotland is a small country"' (McPherson 1976, quoted in Humes 1986, 173).

Tensions increased following what some commentators saw as the attempted anglicisation of Scottish education by the Conservative administrations of 1979-97, through neo-liberal social policy agendas (including competition and testing) that were felt to be inappropriate in Scotland (Paterson, Brown, and Curtis 2001).

\section{Conclusions}

The current relationship between research and policy is uneasy. This section illustrates the history of a changing relationship, which involved a degree of closeness to policy in the past, when social research was seen as providing a scientific basis for the problem-solving actions of government. In the period of post-war reconstruction in the 1940s and 1950s, there was a prevailing political rationality of a post-war welfare state solving social problems, with assistance from researchers. The government of education was managed through a professional bureaucracy that promoted public service and operated discursively in traditional democratic mode. Consensus was pursued and there was some degree of shared power between a partnership of policy-makers at central and local level, and teachers. On the surface, education policy was broadly progressive, education was understood as a public good and educational opportunities were extended as a form of redistribution. The deeper structure exhibited inequalities in resources, opportunities and choices of provision, and underlying elitism and hierarchies of esteem. As problem-solving strategies failed to address the deeper structures, and research focused on the nature of deeply-rooted inequalities, so the policy-research relationship changed. There were differences within the United Kingdom; for example, grammar school education in England was strongly associated with elite occupations and selective (middle-class) mobility, and attracted attention from education researchers who advocated changes in provision. In Scotland, geography and demography combined to promote more inclusive patterns of provision, and so the research-policy relationship may have reflected this.

In both Scotland and England, education policy post-war was not enough to overcome structural inequalities. However, Scotland embraced comprehensive provision in 1965, and has maintained that pattern of provision, with some evidence of impact on social class-related underachievement 
(McPherson and Wilms 1987; Croxford 2000). In England comprehensive provision was not realised, and differentiation remained the hallmark of English provision. After the economic crisis of the late 1970s, even partial consensus on education broke down, and policy was redirected towards economic growth. This laid the basis for policy from the late 1970s onwards, as an increasingly radical Conservative government adopted the ideology of the free market as the core principle for system reorganisation. The Conservative UK governments of 1979-97 legislated to break up state monopolies of provision and encourage consumer choice, to remove state subsidy and ensure competition. The process required simultaneous deregulation and centralisation, as it created the conditions in which markets in education could flourish. Marketisation found a less favourable environment in Scotland than in England: indeed, the modernisation programme was associated with inappropriate English priorities in education.

Education research was shaped by these changing policy contexts.

\begin{abstract}
Sometimes, when [research] does try to be directly relevant to the main policy and political debates, it [seems to be] driven by ideology paraded as intellectual enquiry or critique, setting out with the sole aim of collecting evidence that will prove policy wrong rather than genuinely seeking to evaluate or interpret impact... . I acknowledge that previous criticisms I have made of particular studies have been interpreted by some as denial of evidence which conflicts with policy but we must move forward now ... (Blunkett 2000, 2)
\end{abstract}

\title{
Part 2: Education research and policy: the contemporary context
}

As indicated in Part 1, the relationship between education research and policy in England has been a source of increased interest for some years now (Whitty 2006), and this concern is expressed in a growing body of literature. This interest is not unique to England but reflects responses to developments in the research-policy relationship that are relatively widespread (see, for example, Shavelson and Towne 2002; Roberts 2006; Schneider, Kertcher, and Offer 2006; Sobe 2006). We suggest that responses from researchers to increased policy activity in relation to research may vary according to how they define research and policy: in other words according to how they locate themselves in relation to the different positions and conceptualisations of policy and research outlined in the first section of this review.

Some of this increased policy activity takes the form of auditing existing expertise; some of it reviews the quality of research; while other policy initiatives focus on promoting particular approaches to research. Furlong and White (2001) have recently undertaken a review of current educational research capacity in Wales commissioned by Universities Council for the Education of Teachers. The National Research Council in the USA published a study (Shavelson and Towne 2002) to examine and clarify the nature of scientific inquiry in education and explore how the federal government can best foster and support it. The Scottish Educational Research Association (Kirkwood 2002) is considering how best to encourage further developments of a research strategy for Scotland. Commentators link the increased interest of governments in education (and other) research and their desire to get more 'useful' knowledge from their research spend to developments in the knowledge economy and society (Stehr 2002; Fahey et al. 2006) and this conclusion is supported by official texts (see, for example, European Council 2000; OECD 1996). A slightly different position is taken by researchers who start from the position that research should be policy-relevant, and who offer policy recommendations supported by evidence (see, for example, Sylva et al. 1999; Machin and Vignoles 2005).

\section{The UK Conservative governments}

The current policy preoccupation with improving the usefulness of knowledge produced by social science research (shared by some researchers), with drawing its production closer to the needs of 
government, and with ensuring its improved delivery of value for money and greater responsiveness to economic needs can be tracked back to the Conservative governments of 1979-97, and perhaps particularly to the first Thatcher administration, when Sir Keith Joseph was Secretary of State for Education in England and Wales. From 1981 onwards commentators note a significant change in education policy, with much more interventionist strategies pursued by the then DES, or through new agencies - for example, the Manpower Services Commission (MSC) (Dale 1989). From 1981 there is policy activity aimed at increased harmonisation of vocational education and youth training policy; there is also the rationalisation of education and training for 14-19 as vocational education and exams and assessment are brought together to construct what Ranson described as 'tertiary tripartism' (Ranson 1984). The 'standards agenda' makes its appearance with the policy document 'Better Schools' (1985). In sum, in the opinion of contemporary commentators, Sir Keith Joseph changes the policy-making culture at DES, it becomes much more interventionist, much less bound by convention, and much more inclined to reorganise and legislate in order to achieve its policy ends.

Joseph was also preoccupied with the effective use of resources, in the university sector as well as in schools, and he sought to take more 'direct responsibility' for strategic decisions in the university sector. This brought him into conflict with the traditional research-intensive universities (Kogan and Kogan 1983) and with the Social Science Research Council. Both Thatcher and Joseph were antagonistic towards the social sciences, and believed that social science research was biased towards supporting (self-serving) professional expertise in the public sector, which was the object of their reforms. Over this period, the social sciences were constantly criticised, and Oxford's academics famously took their revenge by denying Thatcher an honorary degree in 1985, in part because they did not believe that basic research had been sufficiently protected from funding cuts and from what they saw as political interference in traditionally autonomous university research (McNay and Ozga 1985).

Reviewing policy research from the 1980s, there is considerable evidence of a research community trying to get to grips with new policy agendas, though often in a rather descriptive way (McNay and Ozga 1985; Ranson and Tomlinson 1986). There is a very considerable increase in publications that scrutinise the content and working of legislation (and there is, of course, a considerable increase in the use of legislation in this period) (see, for example, the edited collections by Flude and Hammer 1990; Coulby and Bash 1991). There are also notable studies of specific policy initiatives - for example, the work of Edwards and Whitty, with Fitz and Gewirtz (Edwards, Fitz, and Whitty 1989; Whitty, Edwards, and Gewirtz 1993) in examining the development and operation of the Assisted Places Scheme and the City Technology Colleges policies, and of Adler, Petch, and Tweedie (1990) in examining school choice policies in Scotland. We gained the impression, from our retrospective analysis, of a field somewhat transfixed by the speed and scope of change, responding for the most part with critical commentary, but also (to a lesser extent) with substantial research studies. Whatever the response, research followed the lead of policy. It is not until the early 1990s that we find substantial material that considers the implications of these policy shifts for research and for understanding research-policy relations (see, for example, the collections edited by Walford 1991, 1994). Some of the contributions to these collections underline the increased difficulty of doing research that produced findings that were not useful, or that did not provide support for a particular policy direction.

In Scotland, as indicated in the previous section, there were considerable tensions following the pursuit by the UK government of market-driven education policies that had little support from the Scottish electorate, where the Conservative government lacked the legitimacy of a significant number of MPs in Scotland. The Centre for Educational Sociology once again provides an interesting example of tension in the research-policy relationship, and the increasing intolerance of government of research that did not endorse its chosen policy directions. In Reconstructions of 
Secondary Education (Gray, McPherson, and Raffe 1983; Grace 1995) there is acknowledgment of a tension between the scepticism of research and the need of government for authority, but despite this tension it is argued that research and government are mutually dependent and need one another. In Raffe's words:

On the one hand, research needs the authority and resources which only the state can provide; on the other hand, effective and democratic government requires critical scrutiny through research, and it requires wide participation in this research by practitioners with experience and insights into the processes of education. (Gray, McPherson, and Raffe 1983, 796)

He goes on to describe the difficulties presented by this orientation to research when a Conservative government "no longer wanted to promote the public interest by supporting access to research among those who might want to criticise its policies' (Gray, McPherson, and Raffe 1983, 796). The Centre's work on comprehensive education, youth training, school performance and access to higher education 'did not endorse the government's prejudices' and with effect from 1993 the Scottish Office ceased to fund the survey activities of the Centre.

\section{The Hargreaves effect}

This highly contested period in education policy formed the backdrop to the continuing policy interest in education research throughout the 1990s. Indeed, in 1991 a working party was set up by ESRC to review education research and set priorities for it (Rudduck and McIntyre 1998, 8-9). A further ESRC review took place in 1995, followed by a Leverhulme review in 1998. However, the debate became heated with the impact made by the criticisms of education research contained in Hargreaves's Teacher Training Agency (TTA) lecture in 1996 (Teaching as a Research-based Profession: Possibilities and Prospects) and previous work (Hargreaves 1994), in which he compared the quality of education research unfavourably with that of medical research. Hargreaves's influential speech encapsulated a number of key criticisms of education research that echoed the concerns of policy-makers.

The main criticisms of education research were/are that:

- It was not cumulative.

- It was fragmented and disparate.

- Sociological research in particular was too theoretical and disconnected from practice.

- It was normative and lacked objectivity and therefore reliability.

- There was no process of research training/formation that established agreed skills/ approaches to enquiry.

- It was poorly articulated with classroom practice.

- It was poorly articulated with policy-making.

While the election of a New Labour government in 1997 brought considerably increased resources for education research in England, along with increased support throughout the United Kingdom through the ESRC Teaching and Learning Research Programme (TLRP) (Furlong 2005; Whitty 2006), it did not diminish the criticisms of education research. These seem to have carried over into the new administration, and the additional resource was largely targeted at funding, aimed at encouraging research in particular policy-relevant areas. The critical appraisal of education research continued under New Labour in 1998 when two reviews of education research in England were published. The first had been commissioned by Ofsted (Tooley and Darby 1998). Entitled Educational Research: A Critique, it offered an analysis by education researchers of the quality of selected research publications. The second (Hillage et al. 1998), entitled Excellence in Research on School, was commissioned by the Department for Education and Employment (DfEE) to analyse the direction, organisation, funding, quality and impact of educational research. While the 
two had related but not identical aims, they echoed Hargreaves' sentiments (Ozga 2000). The report by Hillage et al. concluded that the relationship between research, policy and practice needed to be improved and suggested that the research agenda was too 'supplier' driven. The review noted that the overemphasis on short-term evaluations at the expense of exploration and development in government-sponsored research meant that research was following rather than leading policy. Greater coordination was required in setting research agendas and priorities and in the synthesis and dissemination of research (Hillage et al. 1998). Charles Clarke, then Parliamentary UnderSecretary of State at the DfEE, announced that education research would be 'resurrected' to raise standards, and stressed the need for research that 'can identify the most effective approaches which will contribute to raising standards at all levels (Clarke, in Hillage et al. 1998, 2). This was to be achieved through particular kinds of research (systematic reviews and RCTs were most often mentioned) and through the creation of centres of excellence and user-involvement in setting research priorities.

\section{Research steering}

Meanwhile, the Department for Education and Employment (now the Department for Education and Skills) drew up an action plan to address the recommendations in the Hillage report. The action plan focused on making better use of existing research evidence (through systematic review) and on investing in a better evidence base for the future (Sebba 2004). These agendas were to be realised in part through the setting up in England of a National Forum for Educational Research (NERF; www.nerf.org) and through the establishment of the centre for evidenceinformed policy and practice (http://eppi.ioe.ac.uk). NERF would set priorities for the funding of education research that would coordinate the decisions of all funding agencies for education (Hammersley 2002, 7). At the same time the ESRC TLRP was established, with a framework designed to support research 'which will lead to significant improvements in the achievements of learners' (ESRC 2000).

The first consultation paper produced by NERF (2000) was interpreted by some as a highly instrumental view of research (Gorard 1999; Ball 2001; Ozga 2003; Whitty 2006). This provoked a response from researchers that suggested that 'much of the research community felt that the proposals are centralised, government-driven and a threat to academic freedom and diversity' (NERF 2001, 2). Whitty suggests that hostile responses to this consultation produced a more 'pluralist view of research' (Whitty 2006, 164), but NERF continued to insist on prioritising funding to research that made a 'worthwhile contribution' to policy and practice (NERF 2001).

This brief review of developments provides the context in which some of the very heated current debate is continuing about the quality of education research and about the policies being developed for improvement of that quality. There has been a great deal of discussion, not all of which can be reviewed - or even listed - here (see, for example, Ball 1997; Furlong 1998; Gray 1998; Rudduck and McIntyre 1998; Mortimore and Mortimore 1999; Edwards 2000; Hammersley 2002; Pring and Thomas 2004). A particularly contentious issue has been the identification of preferred approaches to education research, including systematic review (for example see Evans and Benefield 2001; Wilson 2003; Garrett et al. 2005) and random controlled trials, that are seen by some to have stronger claims to scientific validity and reliability (Oakley 2000; Tymms and Fitz-Gibbon 2001; Feuer, Towne, and Shavelson 2002). This view is hotly contested from a number of positions, including: defence of research autonomy (Ball 2001; Gewirtz 2003); defence of alternative conceptualisations of evidence (Hammersley 2002); and defence of alternative conceptualisations of research and its relationship to policy and practice (Hodkinson and Smith 2004).

Nor is this issue likely to decline in significance, as the current UK government has made research a key building block of its approach to policy-making across the range of public services. 
Evidence-based or evidence-informed policy and practice are key to New Labour's modernisation project. David Blunkett, then Secretary of State for Education and Employment (DfEE), in an extract from the 'influence or irrelevance' speech to the ESRC quoted earlier, called for a revolution in policy-research relationships:

Social science should be at the heart of policy-making. We need a revolution in relations between government and the social research community - we need social scientists to help to determine what works and why and what types of policy initiatives are likely to be most effective. (Blunkett 2000)

He went on to call for research that gives a coherent picture of how society operates: the main forces at work and those which can be influenced by government, such as inter-generational poverty, low aspirations, employability, participation in society or exclusion; that evaluates policy initiatives and systematically reviews existing evidence. He also stated that if we are to encourage a more open debate of ideas, we also need "blue skies" research which thinks the unthinkable. If academics do not address this, it is difficult to think of anyone else who will' (Blunkett 2000, 12).

However, in a more critical vein, he noted:

there is a widespread perception, both within and beyond government, that too much social science research is inward-looking, piecemeal rather than helping to build knowledge in a cumulative way, and that issues for research are too 'supplier-driven' rather than focusing on the key issues of concern to policymakers, practitioners and the public at large, especially parents. (Blunkett 2000, 15)

The emergent policy picture, then, is of the redesign of education research to accommodate the pressing needs of policy-makers, and to address key problems in education through providing reliable evidence of what works to policy-makers and practitioners. We consider (below) two sets of responses from researchers to the 'evidence-based' movement.

\section{Researchers and evidence-based policy}

The first comes from researchers who have explored the relationship between research and policy-making, notably the group at the ESRC-funded Research Unit for Research Utilisation (RURU) (www.st-and.ac.uk/ ruru). Nutley and her colleagues argue that there is potential for policy to be better informed by research, and make a number of recommendations for improving both the research and the policy process. On the research side, they note progress in plugging gaps in research knowledge, and in agreement about appropriate research and evaluation methods. They argue that research does not often enter policy as part of a rational consideration of policy options, but enters policy networks through a process of advocacy. In this analysis, then, the research policy relationship could become more productive if the policy process were opened up to become more inclusive and consultative (Nutley 2003a,b). Nutley's main conclusions about the possibilities of bridge-building between research and policy suggest that there needs to be: (a) a realistic appraisal of the role of research and the nature of policy-making; (b) an improvement in the research evidence base through priority setting, capacity-building, agreement about what constitutes robust evidence and methodological development; (c) opening up of the policy process; and (d) the creation of brokering agencies between researchers and policy-makers (Nutley 2003b, 15-16).

This set of arguments attempts to find ways of improving the research-policy relationship that acknowledge the need for change from both researchers and policy-makers. It links to current ideas about the nature of knowledge and knowledge production and exchange that derive from Mode 1 and Mode 2 categorisations of knowledge, in which Mode 1 knowledge is understood as derived from traditional, discipline-based research, while Mode 2 is derived from hybridised research that combines the academy, the state and the private sector (Gibbons et al. 1994). Mode 
2 research encompasses a shift from a linear process of knowledge production and dissemination to an interactive, iterative, problem-focused, trans-disciplinary model (Gibbons et al. 1994; Delanty 2001; Nowotny, Scott, and Gibbons 2001). There are arguments that the strongly contextualised production of Mode 2 knowledge offers opportunities for democratisation of knowledge production in close relationship with society and wider social movements (Nowotny, Scott, and Gibbons 2001, 2003; Liberatore and Funtowicz 2003) as Mode 2 knowledge is required to be 'socially robust' - that is, deemed to be valid not by narrowly defined scientific communities but by wider 'communities of engagement' (Nowotny, Scott, and Gibbons 2003, 183). There is a link, then, to Nutley's call for more interactive, inclusive policy-making. Policy sociologists, however, might point to the capacity of policy-makers and other powerful actors to shape knowledge and policy through their influence on these new forms of contextualised production.

The second set of researcher responses to evidence-based policy-making that we consider here looks at policy responses to research, in particular where the research has produced findings at odds with policy directions. We have included these because they act as a counterpoint to policy statements about the intractability or bias of researchers made by policy-makers (see Blunkett, above). They relate to issues of performance and standards, because of the centrality of these policy areas. They are central to the project of creating a world-class education service (Barber 1998). They also create a need for massive investment by the DfES and the devolved administrations in resources to generate, manage and analyse data on education performance. This research capacity is generated by government for government.

\section{Policy and (some) research at odds? Performance, standards, league tables Standards}

Our first example draws on Peter Mortimore's presidential address to the British Educational Research Association in 1999. In his lecture titled 'Does Educational Research Matter?' Mortimore reviews the importance of education research to society. In a later publication (Mortimore 2000), he states that 'undoubtedly both the last Conservative Government and the current New Labour government genuinely sought - and is seeking to - raise standards'. However, he points out that in their pursuit of improvement, policy-makers have sometimes given the impression that standards have been falling - a position that is not supported by the available evidence.

\section{Monitoring standards: standards in primary schools}

Statutory tests have been publicly available for the end of primary education in England since 1995 (Tymms 2004). A number of studies draw attention to the significance of the rise in statutory test scores at the end of primary school in England since 1995 and question the way that rise is being used to justify policies and to promote certain ways of working, and how they have been used to promote a positive perception of the efficacy of government policies both within England and abroad. However, there has also been concern that the conclusions drawn from a simple examination of the statutory test data are unsafe (Richards 2005). Tymms argued that national testing has failed for a number of reasons:

- The statistical procedures were faulty on one major feature which was not corrected until 2000/01.

- The test data are used in a very high-stakes fashion and the pressure created makes it hard to interpret the data. Teaching test technique must therefore have contributed to some of the rise, as must teaching to the test.

- The official results deal with whole areas of the curriculum (English and mathematics) but the data suggest that standards have changed differently in different sub-areas. Writing 
improved much more than reading. The independent mathematics tests showed different patterns from one another, as did different questions in the textual analysis.

- The form of national tests has changed over time.

- The curriculum evolves and so too does the content of national tests.

- There is concern about the independence of the agencies charged with the preparation of data.

Some policy-makers, notably Michael Barber, former head of the Prime Minister's Delivery Unit, have been particularly active in publicising the gains in performance, and others accept the results uncritically. For example, the National Audit Office (2004) report takes as one its policy examples the introduction of the national literacy strategy and uses as evidence of its success the rise in performance in this statutory test data (Tymms 2004). Both Richards and Tymms illustrate that the current debate on standards is misleading and that the statutory test data cannot be safely used to monitor standards over time, and urge the government to review what it means by standards and how tests reflect those standards.

\section{School effectiveness}

From the 1980s there is a major increase in research on school effectiveness (see Rutter et al. 1979; Gray, McPherson, and Raffe 1983; Steedman 1983; Aitkin and Longford 1986). Mortimore (2000) argues that governments have drawn on the school effectiveness studies in order to claim that if one disadvantaged school can be effective, so can they all. He criticises the development of a nationwide policy on the basis of limited and specific evidence. He points to the way in which the review by Mortimore and Whitty (1997) of the limits of school improvement in tackling the effects of disadvantage was ignored by policy-makers. That review concluded that research tended to support the view that all schools could indeed make a difference but also concluded that there were limits to how much difference was possible and that it was not sensible to try to run an entire system on the basis of what some exceptional schools managed to achieve. Mortimore and Whitty also pointed out that the 'advantaged sometimes gained even more than the disadvantaged from some initiatives' (Mortimore and Whitty 1997).

\section{League tables}

League tables in education, health and local authority services, policing and many other areas have become a prominent feature of social and educational policy (Woodhouse and Goldstein 1988; Goldstein and Meyers 1996). For schools in England, the annual rankings on the basis of examination results have attracted criticism, and even the government that introduced them has conceded that they can be misleading (DfEE 1995). Some recent research (Paterson 1993; Goldstein and Spiegelhalter 1996) indicates that the best available procedures give rankings such that most classes or schools cannot be separated for purposes of comparison. Several reasons are given for this:

- Judgements are always made about a prior group of students or prior state of the institution and the current state may be different;

- The statistical procedure whereby 'adjustments' are made for background factors and prior attainment will only produce estimates within a margin of error so that a great deal of uncertainty about the position of any institution will remain;

- Finally, there may be external factors that are not taken into account, such as household incomes, whose absence will distort comparisons.

These examples of research findings that do not sit well with the direction of policy or do not endorse the claims of policy-makers suggest that the tensions between education research and policy that characterised the 1980s and early 1990s have not disappeared. Other examples are 
given by Whitty (2006) on class size (see Blatchford and Mortimore 1994; Blatchford et al. 2004) and academies (Gorard 2005).

\section{Conclusions}

This review has looked at selected literature on education research and policy, in order to discuss the research-policy relationship, as it has been understood by researchers working in Britain since the 1940s and 50s, through the remaining decades of the twentieth century, and into the contemporary context. The literature reflects the influence on education research, and on the research-policy relationship, of changing political, economic and social contexts in Britain since the post-war period. This is not a history of policy, nor is it an account of major policy developments in education since the war: that would be a much larger task, beyond the scope of this review. Instead, we focus on selected key issues and shifts in the relationship, and illustrate these by reference to key texts, or particular bodies of work, that seem to encapsulate the major preoccupations and characteristics of researchers working in policy-related areas.

In one reading of this review, we could trace a narrative of movement from a modernist post-war project of research as the partner of policy, providing robust and reliable data to government in order to address recognised social problems. The narrative expressed in the literature becomes more complex as we move into the 1960s, and suppressed tensions between research and policy about the ways in which problems are defined and solutions attempted become more and more evident. Thus as the so-called consensus in policy-making fractures, so too does the informal and sometimes inexplicit idea of partnership between researchers and policy-makers. As we note above, this is in part a reflection of developments in research-based knowledge and understanding of educational issues; in part a consequence of new and critical directions in the understanding of power and policy itself; and in part a consequence of economic change and the search by government for higher returns on its investment in education, including research in education. Our review of contemporary responses to these events underlines the extent to which much policy-related research in education responds to policy change in piecemeal and fragmented ways, and without very much explicit attention to what kinds of research-policy relationships are appropriate or possible.

The 1980s sees a further worsening of the research-policy relationship for many researchers, in a period characterised as a 'Pyrrhic victory' (Dale 1992). However, throughout the 1980s and 1990s the literature is rich in policy-relevant studies of particular initiatives (see, for example, Adler, Petch, and Tweedie 1990; Edwards, Fitz, and Whitty 1989, Whitty, Edwards, and Gewirtz 1993). There is a parallel growth in research that is practical and problem-solving, focused on curriculum and management, in which policy is taken for granted or hardly appears. Since 1997, and the election of a UK 'New' Labour government, there has been a more intense dialogue between researchers and policy-makers, that has resulted in a considerable increase in publications that explicitly address the research-policy relationship. This engagement is threaded through the presidential addresses of recent BERA presidents (Edwards 2002; Furlong 2004; Whitty 2006). As the Blunkett speech makes clear, there are contradictions in the attitude of government to research. Government is highly critical of research in education and at the same time strongly committed to research-informed policy. The examples above also suggest that not all research is permitted to inform policy.

A (rather suppressed) theme of this text has been the comparison of research-policy relations in England with those in Scotland - it is acknowledged that this has been a limited comparison, but there are signs of increasing interest in such comparisons. Researchers are beginning to engage with the consequences of devolved polities in the United Kingdom, and to explore differences in 
the ways in which policy uses research in the devolved administrations (Furlong and White 2001). A BERA colloquium on policy and research across the United Kingdom (BERA 2002) suggested that, on the basis of discussion of research-policy relations across the United Kingdom, 'the researcher-policy-maker relationship was not one of "truth speaking to power" but ... of interaction between "truth" and "power" in a shared search for social justice and worthwhile education' (BERA 2002, 9).

In the introduction to the review, we offered some definitions of research, some definitions of policy, and some conceptualisations of the research-policy relationship, that drew on these definitions. We cannot resolve all the differences that we tried to reflect in that discussion. Our intention was not to arrive at a statement of 'the research-policy relationship', but rather to illustrate the ways in which the broad education policy literature reflects different assumptions about what research is, what its purposes are, and how those purposes connect (or don't) to policy. Some of these assumptions reflect very deeply held convictions about the need for independent, critical research on policy that does not easily accommodate pressure for research for policy. Other researchers express different views, and occupy different positions in relation to beliefs about their capacity to inform, and about policy capacity to respond.

The summary of conceptualisations of research-policy relations included discussion of strategic research, which seems to be growing in significance and which reflects ideas about the production of research in collaboration with wider society, including practitioners and policymakers. This version of research accommodates many of the hopes for improvement through research that energise 'engaged' education researchers, as expressed, for example, in the BERA colloquium quoted above. Whether such co-production offers genuinely participative, democratic and inclusive policy-research relationships, or draws researchers into collusion with policy, is a topic for further debate - and research.

\section{Note}

1. The Organisation and Management of Government $R \& D$, by Lord Rothschild, the then head of the government's Central Policy Review Staff, published as an appendix to the Green Paper A Framework for Government Research and Development (Cm 4814, November 1971).

\section{Notes on contributors}

Delma Byrne is a Research Fellow at the Economic and Social Research Institute, Dublin.

Professor Jenny Ozga is Director of the Centre for Educational Sociology and Professor of Education Research at the Moray House School of Education, the University of Edinburgh.

\section{References}

Adler, M., A. Petch, and J. Tweedie. 1990. Parental choice and education policy. Edinburgh: Edinburgh Univ. Press.

Aitkin, M., and N. Longford. 1986. Statistical modelling issues in school effectiveness studies. Journal of Royal Statistical Society A 149: 1-43.

Arnot, M. 1983. A cloud over co-education: An analysis of the forms of transmission of class and gender relations. In Gender class and education, ed. S. Walker and L. Barton. Barcombe: Falmer Press.

Ball, S.J. 1997. Policy sociology and critical social research: A personal review of recent education policy and policy research. British Educational Research Journal 23: 257-74.

—. 2001. "You've been NERFed!" Dumbing down the academy: National Educational Research Forum: "a national strategy-consultation paper": a brief and bilious response. Journal of Education Policy 16: 265-8.

. 2006. Education policy and social class: The selected works of Stephen J. Ball. London and New York: Routledge. 
Banks, O. 1955. Parity and prestige in English secondary education: A study in educational sociology. London: Routledge \& Kegan Paul. 1968. The sociology of education. London: Batsford.

Barber, M. 1998. Creating a world class education service. Speech to the North of England Conference, January 5-7, Bradford.

Baron, G., and D.A. Howell. 1974. The government and management of schools. London: Athlone Press [distributed by Humanities Press, New York].

Bernstein, B. 1961. Social class and linguistic development: a theory of social learning. In Education, economy and society, ed. A.H. Halsey, J. Floud, and A. Anderson. New York: Free Press.

. 1970. Education cannot compensate for society. New Society 387: 344-7.

Birley, D. 1970. The education officer and his world. London: Routledge \& Kegan Paul.

Blatchford, P., P. Bassett, P. Brown, P. Martin, and A. Russell. 2004. The effects of class size on attainment and classroom processes in English primary schools (Years 4 to 6) 2000-2003. London: Department for Education and Skills.

Blatchford, P., and P. Mortimore. 1994. The issue of class size for young children in schools: What can we learn from research? Oxford Review of Education, 20: 411-28.

Blunkett, D. 2000. Influence or irrelevance: Can social science improve government? London: Department for Education and Employment.

Bourdieu, P., and J.C. Passeron. 1977. Reproduction in education, society and culture. London: Sage Publications.

Bowles, S., and H. Gintis. 1976. Schooling in capitalist America: Educational reform and the contradictions of economic life. London: Routledge and Kegan Paul.

Briault, E. 1976. A distributed system of educational administration. Educational Administration 3: 55-63.

British Educational Research Association (BERA). 2002. Educational policy and research across the UK: Report of a BERA colloquium, November 7-8, Edinburgh.

Coulby, D., and L. Bash. 1991. Contradiction and conflict: The 1988 Education Act in action. London: Cassell Educational.

Crowther, Geoffrey Baron. 1959. 15 to 18. London: HMSO.

Croxford, L. 2000. Inequality in attainment at age 16: A "home international" comparison. CES Briefing no. 19, May. Edinburgh: Centre for Educational Sociology.

Dale, R. 1986. Perspectives on policy-making (Module 1 of E333, Policy-making in education). Milton Keynes: Open Univ. Press.

. 1989. The state and education policy. Milton Keynes: Open Univ. Press.

1992. Recovering from a Pyhrric victory? Quality, relevance and impact on the sociology of education. In Voicing concerns: Sociological perspectives on contemporary educational reforms, ed. M. Arnot and L. Barton. Wallingford: Triangle Books.

David, M.E. 1977. Reform, reaction and resources: The 3 Rs of educational planning. Windsor: NFER Publishing Co.

Deary, I., M.C. Whiteman, J.M. Starr, L.J. Whalley, and H.C. Fox. 2004. The impact of childhood intelligence on later life: Following up the Scottish mental surveys of 1932 and 1947. Journal of Personality and Social Psychology 86: 130-47.

Deem, R., A. Parker, and J. Ozga. 2004. Does sociology of education still belong to sociology? Challenges, dilemmas and conflicts. Paper presented at British Sociological Association Annual Conference, April, University of York.

Delanty, G. 2001. Challenging knowledge: The university in the knowledge society. Buckingham: Open Univ. Press.

Department for Education and Employment (DfEE). 1995. GCSE to GCE A-AS value added: Briefing for schools and colleges. London: Department for Education and Employment.

Department of Education and Science (DES). 1964. Provision for research. London: HMSO.

- 1985. Better schools. Cmnd. 9469. London: HMSO.

Dorn, A., and B. Troyna. 1982. Multi-racial education and the politics of decision-making. Oxford Review of Education 8: 175-84.

Douglas, J.W.B. 1964. The home and the school: A study of ability and attainment in the primary school. London: MacGibbon and Kee.

Economic and Social Research Council (ESRC). 2000. Teaching and learning research programme call. Slough: Economic and Social Research Council.

- 2005. Demographic review of UK social sciences. Slough: Economic and Social Research Council. 
Edwards, A. 2002. Responsible ways of being a researcher. BERJ 28, no. 2: 157-69.

Edwards, T. 2000. "All the evidence shows ...": Reasonable expectations of educational research. Oxford Review of Education 26: 299-311.

Edwards, T., J. Fitz, and G. Whitty. 1989. The state and private education: An evaluation of the Assisted Places Scheme. London and New York: Falmer Press.

European Council. 2000. Presidency conclusions. Lisbon European Council, March 23-24, Lisbon.

Evans, J., and P. Benefield. 2001. Systematic reviews of educational research: Does the medical model fit? British Educational Research Journal 27: 527-41.

Fahey, J., J Kenway, E. Bullen, and S. Robb. 2006. Knowledge beyond the knowledge economy: Merely cultural? Merely commercial? Merely civilizing? In World yearbook of education 2006: Education research and policy: Steering the knowledge-based economy, ed J. Ozga, T. Seddon, and T.S. Popkewitz. London and New York: Routledge.

Fay, B. 1975. Social theory and political practice. London: Allen and Unwin.

Feuer, M.L. 2002. Scientific culture and educational research. Educational Researcher 31: 4-14.

Fletcher, J. 1995. Policy-making in DES/DfE via consenus and contention. Oxford Review of Education 21: $133-48$.

Floud, J., A.H. Halsey, and F.M. Martin. 1956. Social class and educational opportunity. London: Heinemann.

Flude, M., and M. Hammer. 1990. The Education Reform Act, 1988: Its origins and implications. London and New York: Falmer Press.

Furlong, J. 1998. Educational research: Meeting the challenge. Inagural lecture, Univ. of Bristol. 2004. BERA at 30: Have we come of age? BERJ 30, no. 3: 339-43.

2005. New Labour and teacher education: The end of an era. Oxford Review of Education 31: $119-34$.

Furlong, J., and P. White. 2001. Educational research capacity in Wales: A review. Cardiff: School of Social Sciences, Cardiff Univ.

Garrett, Z., M. Newman, D. Elbourne, S. Bradley, J. Taylor, and A. West. 2005. Secondary school size: A systematic review. In Research evidence in education library. London: EPPI-Centre, Social Science Research Unit, Institute of Education, Univ. of London.

Gewirtz, S. 2003. Enlightening the research-policy relationship: Issues and dilemmas for educational researchers. Paper presented at European Educational Research Association Annual Conference, September, Hamburg, Germany.

Gewirtz, S., and J. Ozga. 1990. Partnership, pluralism, and education policy: A reassessment. Journal of Educational Policy 5: 37-48.

Gibbons, M., C. Limoges, H. Nowonty, and S. Schwartzman. 1994. The new production of knowledge: The dynamics of science and research in contemporary societies. London and Thousand Oaks, CA: Sage Publications.

Goldstein, H., and K. Meyers. 1996. Freedom of information: Towards a code of ethics for performance indicators. Research Intelligence 57: 12-16.

Goldstein, H., and D. Spiegelhalter. 1996. League tables and their limitations: Statistical issues in comparisons of international performance. Journal of Royal Statistical Society Series A 159: 385-443.

Gorard, S. 1999. Well. That about wraps it up for school choice research: A state of the art review. School Leadership and Management 19: 25-47.

.2005. Academies as the "future of schooling": Is this an evidence-based policy? Journal of Education Policy 20: 369-77.

Gosden, P. 1966. The development of educational administration in England and Wales. Oxford: Basil Blackwell.

Grace, G.R. 1995. School leadership: Beyond education management an essay in policy scholarship. London and Washington, DC: Falmer Press.

Gray, J. 1998. The contribution of educational research to the cause of school improvement. Professorial lecture, Institute of Education, Univ. of London.

Gray, J., A. McPherson, and D. Raffe. 1983. Reconstructions of secondary education: Theory, myth and practice since the war. London and Boston, MA: Routledge \& Kegan Paul.

Halsey, A.H. 1997. Education: Culture, economy, and society. Oxford and New York: Oxford Univ. Press.

Halsey, A.H., J.E. Floud, and C.A. Anderson. 1961. Education, economy, and society: A reader in the sociology of education. New York: Free Press of Glencoe; London: Collier-Macmillan.

Halsey, A.H., A. Heath, and J.M. Ridge. 1980. Origins and destinations: Family, class, and education in modern Britain. Oxford and New York: Clarendon Press, Oxford Univ. Press. 
Hammersley, M. 2000a. Case study method: Key issues, key texts. London: Sage.

2000b. Varieties of social research: A typology. International Journal of Social Research Methodology 3: 221-9.

- 2002. Educational research, policymaking and practice. London: Paul Chapman.

Hargreaves, D.H. 1994. The mosaic of learning: Schools and teachers for the next century. London: DEMOS.

Heath, A. 2000. The political arithmetic tradition in the sociology of education. Oxford Review of Education 26: $313-31$.

Heath, A., and S. Jacobs. 1999. Comprehensive reform in Britain. In The comprehensive school experiment revisited: Evidence from western Europe, ed A. Leschinsky and K.U. Mayer, 101-30. Frankfurt am Main: Peter Lang.

Hillage, J., R. Pearson, A. Anderson, and P. Tamkin. 1998. Excellence in research on schools. Sudbury: DfEE, Institute for Employment Studies.

Hodkinson, P., and J. Smith. 2004. The relationship between research, policy and practice. In Evidencebased practice in education, ed. G. Thomas and R. Pring. Maidenhead: Open Univ. Press

Hogben, L.T. 1938. Political arithmetic: A symposium of population studies. London: G. Allen \& Unwin.

Humes, W.M. 1986. The leadership class in Scottish education. Edinburgh: John Donald.

Inner London Education Authority (ILEA). 1982. Sex differences in achievement. London: Inner London Education Authority.

- 1983a. Anti-sexist initiatives in ILEA schools. London: Inner London Education Authority.

1983b. Race, sex and class: Multi-ethnic education in schools. London: Inner London Education Authority.

. 1985. A policy for equality. London: Inner London Education Authority.

Johnson, P. 2004. Making social science useful. British Journal of Sociology 55: 23-30.

Kenway, J., E. Bullen, and S. Robb. 2004. The knowledge economy, the technopreneur and the problematic future of the university. Policy Futures in Education 2 (Special Issue on University Futures, ed. M. Marginson and M. Peters): 333-51.

Kirkwood, M. 2002. Educational research in Scotland: Policy, context and key issues. Research Intelligence 79: 33-41.

Kirp, D.L. 1984. Racial inexplicitness and education policy. In Race and gender: Equal opportunities in education, ed. M. Arnot. Oxford: Pergamon Press/The Open Univ.

Kogan, M., E.B. Boyle, and A. Crosland. 1971. The politics of education. Harmondsworth: Penguin Books.

Kogan, M., and D. Kogan. 1983. The attack on higher education. London: Kogan Page.

Kogan, M., and K. Mansfield. 1975. Educational policy-making: A study of interest groups and Parliament. London: Allen \& Unwin.

Lauder, H., P. Brown, and A.H. Halsey. 2004. Sociology and political arithmetic: Some principles of a new policy science. British Journal of Sociology 55: 3-22.

Lawn, M. 1987. The spur and the bridle: Changing the mode of curriculum control. Journal of Curriculum Studies 19: 227-36.

- 2004. The institute as network: The Scottish Council for Research in Education as a local and international phenomenon in the 1930s. Paedagogica Historica 40: 719-32.

Lawn, M., and J. Furlong. 2007. The social organisation of education research in England. European Educational Research Journal 6, no. 1: 55-70.

Lawn, M., and J. Ozga. 1986. Unequal partners: Teachers under indirect rule. British Journal of Sociology of Education 7: 323-36.

Lawrence, B. 1972. The administration of education in Britain. London: B.T. Batsford.

Liberatore, A., and S. Funtowicz. 2003. Democratising expertise, expertising democracy: What does this mean and why bother? Science and Public Policy June: 146-50.

Machin, S., and A. Vignoles. 2005. What's the good of education? The economics of education in the UK. Princeton, NJ and Oxford: Princeton Univ. Press.

McNay, I., and J. Ozga. 1985. Policy-making in education: The breakdown of consensus: A reader. Oxford: Pergamon in association with the Open Univ.

McPherson, A. 1976. An episode in the control of research. In An attitude of mind: Twenty-five years in education: 50th Anniversary, 1928-1978, ed. W.B. Dockrell. Edinburgh: SCRE.

McPherson, A., and C.D. Raab. 1988. Governing education: A sociology of policy since 1945. Edinburgh: Edinburgh Univ. Press.

McPherson, A.F., and J.D. Wilms. 1987. Equalisation and improvement: Some effects of comprehensive organisation in Scotland. Sociology 21: 509-39. 
Miller, P., and N. Rose. 1993. Governing economic life. In Foucault's new domains, ed M. Gane and T. Johnson, 75-105. London: Routledge.

Moore, R. 1996. Back to the future: The problems of change and possibilities of advance in the sociology of education. British Journal of Sociology of Education 17: 145-62.

Morris, J.G., and F. Hope Johnston. 1981. The impact of policy and practice on research. British Journal of Educational Studies 29: 209-17.

Mortimore, P. 2000. Issues in education research: Problems and possibilities. Oxford Review of Education 26: $503-7$.

Mortimore, P., and J. Mortimore. 1999. Does educational research influence policy or practice? In The future of education research, ed. I. Abbott. London: Falmer.

Mortimore, P., and G. Whitty. 1997. Can school improvement overcome the effects of disadvantage? London: Univ. of London, Institute of Education.

Musgrave, P.W. 1970. Sociology, history and education: A reader. London: Methuen.

Musgrove, F. 1971. Patterns of power and authority in English education. London: Methuen.

National Audit Office. 2004. Skills for life: Improving adult literacy and numeracy. London: House of Commons.

National Education Research Forum (NERF). 2000. Research and development in education: A national strategy consultation paper. Nottingham: NERF Publications.

- 2001. A research and development strategy for education: Developing quality and diversity. Nottingham: NERF Publications.

National Union of Teachers (NUT). 1982. Education for a multi-cultural society. London: National Union of Teachers.

. 1984. Combating racism in schools. London: National Union of Teachers.

Nisbet, J. 1985. World yearbook of education: Research policy and practice. London and New York: Kogan Page, Nichols.

. 2005. What is educational research? Changing perspectives through the 20th century. Research Papers in Education 20: 25-44.

Nisbet, J., and P. Broadfoot. 1980. The impact of research on policy and practice in education. Aberdeen: Aberdeen Univ. Press.

Nowotny, H., P. Scott, and M. Gibbons. 2001. Re-thinking science: Knowledge and the public in an age of uncertainty. Cambridge: Polity.

. 2003. Mode 3 revisited: The production of knowledge. Minerva 41: 179-94.

Nutley, S. 2003a. Bridging the policy-research divide: Reflections and lessons from the United Kingdom. Canberra Bulletin of Public Administration 10: 19-28.

- 2003b. Bridging the policy/research divide. Reflections and lessons from the UK. In keynote paper presented at 'Facing the future: Engaging stakeholders and citizens in developing public policy', National Institute of Governance Conference, November, Canberra, Australia.

Oakley, A. 2000. Experiments in knowing: Gender and method in the social sciences. Cambridge: Polity Press. Open University. 1981. Society, education and the state. Milton Keynes: Open Univ. Press.

1986. Policy-making in education. Milton Keynes: Open Univ. Press.

Organisation for Economic Co-operation and Development (OECD). 1975. Educational development strategy in England and Wales. Paris: OECD.

-1996. The knowledge-based economy. Paris: OECD.

2002. The measurement of scientific and technical activities: Proposed standard practice for surveys of research and experimental development; Frascati manual 2002. Paris: OECD.

Ozga, J. 1987. Studying education through the lives of policy makers: An attempt to close the macro-micro gap. In Changing policies, changing teachers: New directions in schooling, ed. L. Barton and S. Walker. Lewes: Falmer Press.

-2000. Policy research in educational settings: Contested terrain. Buckingham: Open Univ. Press. . 2003. Researching education policy: Interpreting the evidence. In Handbook of educational leadership and management, ed. B. Davies and J. West-Burnham. London: Pearson Collins.

. 2007. Co-production of quality in the Applied Education Research Scheme. Research Papers in Education 22, no. 2: 169-83.

Ozga, J., T. Seddon, and T.S. Popkewitz. 2006. World yearbook of education 2006: Education research and policy: Steering the knowledge-based economy. London and New York: Routledge.

Paterson, L. 1993. A commentary on methods currently being used in Scotland to evaluate schools statistically. In Measuring schools: The rights and wrongs of practice in Scotland, ed. L. Paterson. Edinburgh: Centre for Educational Sociology. 
2003. Scottish education in the twentieth century. Edinburgh: Edinburgh Univ. Press.

Paterson, L., A. Brown, and J. Curtis. 2001. New Scotland, new politics? Edinburgh: Polygon at Edinburgh. Pile, W. 1976. Evidence quoted in the Tenth Report of the Expenditure Committee: Decision making in the DES. London: HMSO.

Power, S. 1992. Researching the impact of education policy: Difficulties and discontinuities. Journal of Education Policy 75: 493-500.

Pring, R., and G. Thomas. 2004. Evidence-based practice in education. Maidenhead: Open Univ. Press.

Ranson, S. 1984. Towards a tertiary tripartism: New codes of social control and the 17-plus. Brighton: Falmer.

Ranson, S., and J.R.G. Tomlinson. 1986. The changing government of education. London and Boston, MA: Allen \& Unwin for the Institute of Local Government Studies, Univ. of Birmingham.

Richards, C. 2005. Standards in English primary schools: Are they rising? London: Association of Teachers and Lecturers.

Roberts, P. 2006. Performativity, measurement and research. In World yearbook of education 2006: Education research and policy, ed. J. Ozga, T. Seddon, and T.S. Popkewitz. London and New York: Routledge.

Rothschild, Lord. 1971. The organisation and management of government R\&D. London: HMSO.

- 1982. An enquiry into the Social Science Research Council. London: HMSO.

Royal County of Berkshire. 1983. Education for race equality. Reading Education Department.

Rudduck, J., and D. McIntyre. 1998. Challenges for educational research. London: Paul Chapman.

Rutter, M., B. Maughan, P. Mortimore, J. Ouston, and A. Smith. 1979. Fifteen thousand hours: Secondary schools and their effects on children. Cambridge, MA: Harvard Univ. Press.

Saran, R. 1973. Policy-making in secondary education. A case study. Oxford: Clarendon Press.

Schneider, B., Z. Kertcher, and S. Offer. 2006. Global trends towards education and science: Tension and resistance. In World yearbook of education 2006: Education research and policy, ed. J. Ozga, T. Seddon, and T.S. Popkewitz. London and New York: Routledge.

Sebba, J. 2004. Developing an evidence based approach to policy and practice in education. York: Higher Education Academy.

Seddon, T. 1996. The principle of choice in policy research. Journal of Education Policy 2: 200-14.

Shavelson, R.J., and L. Towne. 2002. Scientific research in education. Washington, DC: National Research Council, National Academy Press.

Simon, B. 1985. Does education matter? London: Lawrence and Wishart. . 1991. Education and the social order, 1940-1990. London: Lawrence and Wishart.

Sobe, N.W. 2006. Accountability in US educational research and the travels of governance. In Worldyearbook of education 2006: Education research and policy, ed. J. Ozga, T. Seddon, and T.S. Popkewitz. London and New York: Routledge.

Social Sciences: News from the ESRC. 1998. Resurrecting research to raise standards. October: 2.

Stanworth, M. 1983. Gender and schooling: A study of the social divisions in the classroom. London: Hutchinson.

Steedman, J. 1983. Examination results in selective and nonselective schools: Findings from the National Child Development Study. London: National Children's Bureau.

Stehr, N. 2002. Knowledge and economic conduct: The social foundations of the modern economy Toronto, ON: Univ. of Toronto Press.

Sylva, C., E. Melhuish, S. Sammons, and I. Sira-Blatchford. 1999. Characteristics of the centres in the EPE sample: Observational profiles. Technical paper 6. London: Institute of Education.

Tomlinson, S. 1984. The "black education" movement. In Race and gender: Equal opportunities in education, ed. M. Arnot. Oxford: Pergamon Press/Open Univ.

Tooley, J., and D. Darby. 1998. Educational research: A critique: A survey of published educational research. London: Office for Standards in Education.

Troyna, B. 1982. The ideological and policy response to black pupils in British schools. In The social sciences in educational studies, ed. A. Hartnett, 127-43. London: Heinemann.

-1994. Critical social research and education policy. British Journal of Educational Studies 42: 70-84.

Tymms, P. 2004. Are standards rising in English primary schools? British Educational Research Journal 30: 477-94.

Tymms, P., and C. Fitz-Gibbon. 2001. Standards, achievement and educational performance: A cause for celebration? In Education, reform and the state: Twenty-five years of politics, policy and practice, chapter 11, ed. R. Phillips and J. Furlong, 156-73. London: RoutledgeFalmer.

Walford, G. 1991. Doing educational research. London: Routledge. . 1994. Researching the powerful in education. London: UCL Press.

Weaver, T., Sir. 1979. The control of education in Britain. Milton Keynes: Open Univ. Press. 
Weiner, G. 1985. Just a bunch of girls. Milton Keynes: Open Univ. Press.

Weiss, C.H. 1991. Policy research: Data, ideas or arguments? In Social sciences and modern states: National experiences and theoretical crossroads, ed. P. Wagner, C. Weiss, B. Wittrock, and H. Wollmann. Cambridge: Cambridge Univ. Press.

Whitty, G. 2006. Education(al) research and education policy making: Is conflict inevitable? British Educational Research Journal 32: 159-76.

Whitty, G., T.Edwards, and S. Gewirtz. 1993.Specialisation and choice in urbaneducation: The citytechnology college experiment. London: Routledge.

Wilson, D. 2003. Which ranking? The use of alternative performance indicators in the English secondary education market. Bristol: Department of Economics, Univ. of Bristol.

Woodhouse, G., and H. Goldstein. 1988. Educational performance indicators and league tables. Oxford Review of Education 14: 301-20.

Yates, L. 2004. What does good education research look like? Situating a field and its practices. Maidenhead: Open Univ. Press. 